\author{
ACTA MYCOLOGICA \\ Vol. 43 (2): 215-230 \\ 2008
}

\title{
Lichens in the rural landscape of the Warmia Plain
}

\author{
RAFAŁ SZYMCZYK and ANNA ZALEWSKA \\ Department of Botany and Nature Protection, University of Warmia and Mazury in Olsztyn \\ Pl. Łódzki 1, PL-10-727 Olsztyn, graphis22@poczta.onet.pl
}

Szymczyk R., Zalewska A. Lichens in the rural landscape of the Warmia Plain. Acta Mycol. 43 (2): 215-230, 2008.

Lichens and lichenicolous fungi in the rural landscape of the Warmia Plain were studied. Lichen species were observed on old wooden fences, roadside trees, fruit trees, pylons, farm machinery, buildings and bridges. The analysed biota consists of 104 taxa with several noteworthy and rare lichens.

Key words: lichenized and lichenicolous fungi, anthropogenic habitats, N Poland

\section{INTRODUCTION}

The Warmia Plain is the most easterly mesoregion of the Littoral Gdańsk Region. It is situated to the east and north-east of the Elblacg High Plain, and it occupies an area of around $640 \mathrm{~m}^{2}$ (Kondracki 2001). The plain slopes down mostly to the north from the altitude of $60-70 \mathrm{~m}$ to $20 \mathrm{~m}$ above sea level and scarps down to the Old Prussian Coast stretching along the Vistula Lagoon. The Warmia Plain is partially covered with varved clay from the recession period of the Pomeranian phase of Vistula Glaciation, while the ground surface in the southern area near Pasłęk consists of boulder clay. Extensive farm fields and pastures separated by woods are the predominant features of the local landscape. The region is intersected by the rivers Bauda and Pasłęka whose deep valleys cut into the local relief.

The lichen biota of nearly completely deforested rural areas is rarely individually studied (Kuziel 1964). Data concerning lichens in such habitats are found in most lichenological studies investigating large areas, but they are difficult to isolate from the general context (e.g. Fałtynowicz and Tobolewski 1989; Cieśliński 2003; Czyżewska 2003a). Comparative data can be found in selected monographs which separately analyse the diversity of non-synanthropic and apophytic lichens (e.g. Fałtynowicz 1992; Bystrek and Kolanko 2000) or in studies devoted to the synanthropization of lichen biota (articles from the collection of Kiszka and Piórecki 1994 (eds), e.g. Kiszka 1994, Fałtynowicz 1994; Cieśliński and Czyżewska 1998, Olech 1998). 
The Warmia Plain is weakly researched as regards its lichen population. The most abundant source of data is an unpublished study by Woźniak (1983), which discusses mostly lichens on roadside trees along the main roads of the region. Information on the localities of several species can also be found in the papers by Sulma and Fałtynowicz (1988), Fałtynowicz and Sulma (1994), as well as in atlases (Tobolewski 1983, 1988).

The objective of this study was to record species of lichens, lichenicolous and saprotrophic fungi growing on various anthropogenic substrates in a man-transformed rural landscape.

\section{STUDY AREA}

The studied site was the village of Nowica in the Warmia Plain in northern Poland (Fig. 1). This small village is situated in the Wilczęta municipality, county of Braniewo. It has a population of around 100 inhabitants and features housing typical of former German settlements. All farms and public utility buildings form a single cluster surrounded by farm fields and pastures. The village is intersected by a nameless river, a tributary of the Bauda River. Nowica is the crossing point of two provincial roads with old roadside oaks, awarded the status of natural monuments, as well as younger ash and linden trees. The investigated site is situated in square $\mathrm{Bd} 08$ of the ATPOL grid (modified for lichens by Cieśliński and Fałtynowicz 1993) inside an area mapped by lines with the following geographic coordinates: $54^{\circ} 10^{\prime} 53.9^{\prime \prime}-$ $54^{\circ} 11^{\prime} 27.4^{\prime \prime} \mathrm{N} / 19^{\circ} 48^{\prime} 21.2^{\prime \prime}-19^{\circ} 48^{\prime} 45^{\prime \prime} \mathrm{E}$.

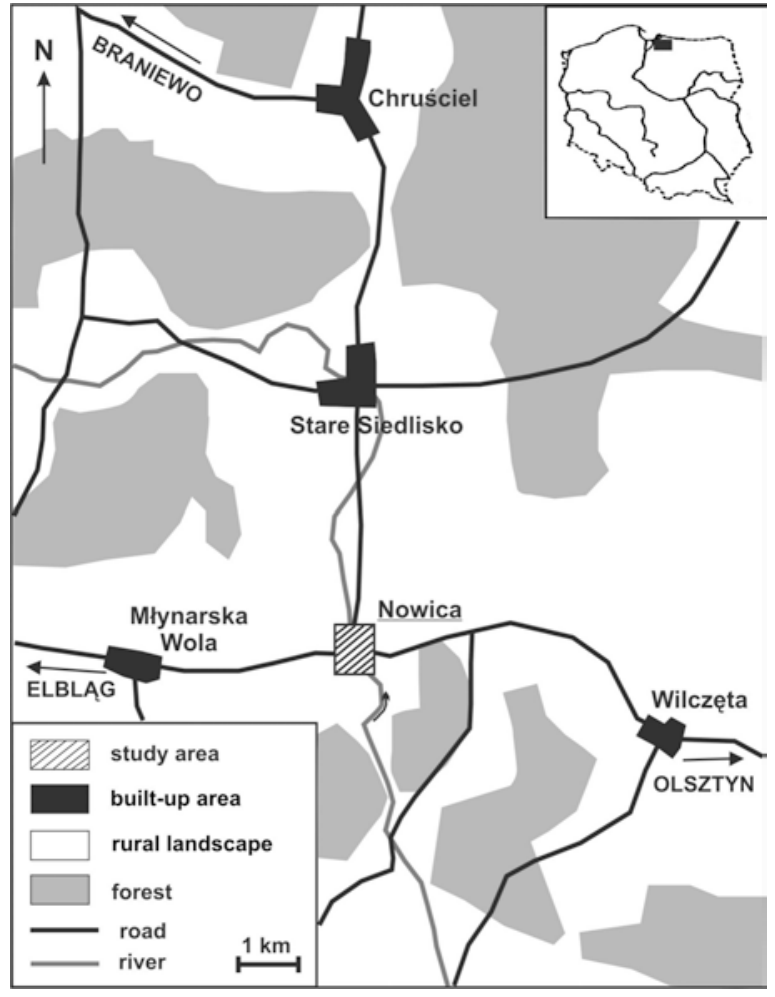

Fig. 1. Location of the investigated area 


\section{MATERIALS AND METHODS}

The experimental material was collected by the first author between 2001 and 2006 within the administrative boundaries of the village of Nowica. During field observations, the author compiled records of the local biota and collected around 100 samples of lichen thalli from various substrates, including the bark of roadside trees, fruit trees, riverside trees, old wooden fences, farm buildings, field stakes, concrete fences, posts, bridges, roof tiles, asbestos-cement roofing material, granite border posts and metal parts of farm machinery.

The collected material was analyzed by standard morphological and anatomical methods. The composition of secondary lichen metabolites was used to identify species of the genus Lepraria and other lichens with sterile and crustose thalli. Lichen substances were studied by thin-layer chromatography (Orange et al. 2001). The applied nomenclature follows Fałtynowicz (2003), excluding Bacidia adastra (Sparrius and Aptroot 2003) and the following genera: Coenogonium (Kauff and Büdel 2005), Melanelixia and Melanohalea (Hawskworth et al. 2008) and Piccolia (Hafellner 2004). The collected material was deposited in the Herbarium of the Department of Botany and Nature Protection, University of Warmia and Mazury in Olsztyn (OLS-L).

\section{RESULTS}

A total of 96 lichen species and 8 species of non-lichenized fungi (including 7 species of lichenicolous fungi and 1 species of saprotrophic fungi) were identified in the research area. Below is an alphabetic list of the noted taxa. The number of records in the studied area and substrate types are given for every taxon. The relevant categories of threatened species, according to Cieśliński et al. (2006), are indicated for vanishing lichens in Poland. Protected species (Regulation of the Ministry of the Environment 2004) are marked with the letter "P". Lichenicolous fungi are marked with an asterisk $(*)$, and saprobionts - with a plus sign $(+)$.

\section{LIST OF SPECIES}

Acarospora fuscata (Schrad.) Th. Fr.

2 records; on roof tiles; 12 July 2005 (OLS-L 371).

Amandinea punctata (Hoffm.) Coppins \& Scheid.

22 records; on the bark of oak, apple tree, ash, horse-chestnut, linden, alder, poplar, willow and cherry tree, on wood and roof tiles; 12 July 2005 (OLS-L). Also recorded by Woźniak (1983).

Anaptychia ciliaris (L.) Körb.

3 records; on the bark of ash and oak; 14 July 2005 (field record, not collected), P. Also recorded by Woźniak (1983).

Anisomeridium polypori (M.B. Ellis \& Everh.) M.E. Barr

4 records; on the bark of ash, alder and willow; 14 July 2005 (OLS-L 297). 
*Athelia arachnoidea (Berk.) Jülich

1 record; on thallus and apothecia of Lecanora conizaeoides growing on an alder; 12 July 2005 (OLS-L).

Bacidia adastra Sparrius \& Aptroot

1 record; on the bark of apple tree; 25 Dec. 2005, rev. M. Kukwa (OLS-L 416).

Bacidina phacodes (Körb.) Vězda

1 record; on the bark of willow; 14 Aug. 2001 (OLS-L 292).

Buelia griseovirens (Turner \& Borrer ex Sm.) Almb.

4 records; on the bark of alder and wood; 20 Aug. 2005 (OLS-L 395).

Caloplaca citrina (Hoffm.) Th. Fr.

3 records; on concrete; 18 Aug. 2001 (OLS-L 283).

C. decipiens (Arnold) Blomb. \& Forssel

3 records; on cement-asbestos roofing material and concrete; 15 Aug. 2005 (field record, not collected).

C. flavocitrina (Nyl.) A. E. Wade

1 record; on concrete; 12 Aug. 2005 (OLS-L 398).

C. holocarpa (Hoffm.) A. E. Wade

6 records; on the bark of elder, cement-asbestos roofing material, wood, concrete and metal; 12 July 2005 (OLS-L).

C. obscurella (J. Lahm) Th. Fr.

1 record; on the bark of willow; NT; 15 Aug. 2001 (OLS-L 291).

C. saxicola (Hoffm.) Nordin

7 records; on cement-asbestos roofing material and concrete; 1 March 2005 (OLS-L 284).

Candelaria concolor (Dicks.) Stein

5 records; on the bark of linden, alder, willow, on wood; 1 March 2005 (OLS-L).

Candelariella aurella (Hoffm.) Zahlbr.

5 records; on cement-asbestos roofing material, concrete and metal, 1 March 2005 (OLS-L).

\section{C. reflexa (Nyl.) Lettau}

20 records; on the bark of oak, apple tree, ash, maple, linden, alder, poplar, willow, on wood; 14 July 2005 (OLS-L 296, 345).

C. xanthostigma (Ach.) Lettau

12 records; on the bark of oak, apple tree, ash, maple, poplar, willow, on wood; 21 Sept. 2005 (OLS-L).

C. vitellina (Hoffm.) Müll. Arg.

3 records; on roof tiles and metal; 12 July, 21 Sept. 2005 (OLS-L 368, 373). Also recorded by Woźniak (1983).

\section{Chaenotheca trichialis (Ach.) Th.Fr.}

1 record; on wood; 10 Aug. 2005 (OLS-L 385). NT category.

+Chaenothecopsis savonica (Räsänen) Tibell

1 record; on wood; 10 Aug. 2005 (OLS-L 386). 
Note. This species is usually parasitic or parasymbiontic on lichen thalli or on algae (e.g. Sparrius 2003; Groner 2006), but it can also grow on wood (see Szymczyk 2007).

Cladonia fimbriata (L.) Fr.

4 records; on apple tree bark and on wood; 25 Dec. 2004 (OLS-L 286).

C. polydactyla (Flörke) Spreng.

1 record; on wood; 21 Sept. 2005, (OLS-L).

Coenogonium pineti (Schrad. ex Ach.) Lücking \& Lumbsch

3 records; on the bark of alder; 14 July 2005, (OLS-L).

Evernia prunastri (L.) Ach.

11 records; on the bark of oak, pear tree, apple tree, ash, maple, linden and alder, on wood; 26 March 2005 (OLS-L 332). NT category, P. Also recorded by Woźniak (1983).

\section{Hypocenomyce scalaris (Ach.) M. Choisy}

6 records; on the bark of oak, ash, alder, on wood; 12 July 2005 (field record, not collected).

\section{Hypogymnia physodes (L.) Nyl.}

24 records; on the bark of elder, oak, pear tree, apple tree, ash, maple, linden, alder, willow, cherry tree, on wood; 20 July 2004 (field record, not collected). Also recorded by Woźniak (1983).

H. tubulosa (Schaer.) Hav.

4 records; on the bark of oak and ash; 20 July 2004 (OLS-L 300). NT category, P.

Lecania cyrtella (Ach.) Th. Fr.

2 records; on the bark of elder; 20 Sept. 2005 (OLS-L 288).

Lecanora albescens (Hoffm.) Flörke

6 records; on concrete; 1 March 2005 (OLS-L 347).

L. allophana (Ach.) Nyl.

1 record; on ash bark; 20 July 2004 (OLS-L 304).

L. argentata (Ach.) Malme

6 records; on the bark of oak, maple and poplar, on wood, 7 Aug. 2005 (OLS-L 348). Also recorded by Woźniak (1983).

L. carpinea (L.) Vain.

11 records on the bark of elder, oak, ash, horse-chestnut, hazel, linden, poplar, cherry tree, on wood; 20 Sept. 2005 (OLS-L 346). Also recorded by Woźniak (1983).

L. chlarotera Nyl.

6 records; on the bark of oak, apple tree, ash, maple and poplar; 20 July 2004 (OLS-L). Also recorded by Woźniak (1983).

L. conizaeoides Crombie

7 records; on the bark of linden, spruce, cherry tree, on wood and metal; 15 July 2005 (OLS-L). 
L. dispersa (Pers.) Sommerf.

5 records; on concrete; 15 July 2005 (OLS-L). Also recorded by Woźniak (1983).

L. expallens Ach.

3 records; on the bark of oak, ash and poplar; 21 Sept. 2005 (OLS-L), (TLC 033/11). Also recorded by Woźniak (1983).

L. hagenii (Ach.) Ach.

2 records; on the bark of elder and on wood; 14 May 2004 (OLS-L).

L. persimilis (Th. Fr.) Nyl.

1 record; on wood; 12 Aug. 2005 (OLS-L 420). DD category.

L. rugosella Zahlbr.

1 record; on the bark of alder; 21 Sept. 2005 (OLS-L).

L. saligna (Schrad.) Zahlbr.

4 records; on the bark of willow and on wood; 3 Sept. 2001 (OLS-L 298). Also recorded by Woźniak (1983).

L. symmicta (Ach.) Ach.

5 records; on the bark of plum tree, willow, cherry tree, on wood; 20 Sept. 2005 (OLS-L 334).

L varia (Hoffm.) Ach.

4 records; on the bark of oak and on wood; 20 July 2005, (OLS-L 294). Also recorded by Woźniak (1983).

Lecidella elaeochroma (Ach.) Choisy

12 records; on the bark of elder, apple tree, horse-chestnut, maple, hazel, linden, alder, poplar, willow, on wood; 7 Aug. 2001 (OLS-L 349). Also recorded by Woźniak (1983).

L. flavosorediata (Vězda) Hertel \& Leuckert

1 record; on the bark of poplar; 20 July 2004, 10 June 2006; rev. M. Kukwa (TLC 033/10) (OLS-L 321, 680).

L. scabra (Taylor) Hertel \& Leuckert

2 records; on roof tiles; NT category; 14 Sept. 2005, det. M. Kukwa (TLC 2/2007/15,16) (OLS-L 417).

L. stigmatea (Ach.) Hertel \& Leuckert

2 records; on concrete; 29 Sept. 2005 (OLS-L 295).

Lepraria incana (L.) Ach.

7 records; on the bark of oak, ash, linden and alder, on wood; 20 July 2004 (OLSL 313, 314, 318).

L. vouauxii (Hue) R. C. Harris

2 records; on the bark of ash and wood; 10 July 2004; det. M. Kukwa (TLC 16/730) (OLS-L 322, 323).

*Lichenoconium erodens M. S. Christ. \& D. Hawksw. et D. Hawksw.

2 records; on thalli of Lecanora sp. growing on wood, 10 July 2004 (OLS-L). 
*L. xanthoriae M.S. Christ.

1 record; on apothecia of Xanthoria parietina growing on willow, 11 Oct. 2005 (OLS-L 392).

*Lichenodiplis lecanorae (Vouaux) Dyko \& D. Hawksw.

2 record; on apothecia of Lecanora chlarotera growing on ash; 25 Dec. 2004 (OLS-L 342).

Melanelixia subargentifera (Nyl.) O. Blanco et al.

1 record; on ash bark; 9 May 2005 (OLS-L 351). VU category, P.

M. subaurifera (Nyl.) O. Blanco et al.

1 record; on the bark of alder; 9 May 2005 (OLS-L 354). P.

Melanohalea exasperatula (De Not.) O. Blanco et al.

16 records; on the bark of oak, apple tree, ash, alder, poplar, willow, cherry tree, on wood; 20 Sept. 2005 (OLS-L 333). P. Also recorded by Woźniak (1983).

Micarea denigrata (Fr.) Hedl.

4 records; on wood; 10 June 2005 (OLS-L 374).

M. misella (Nyl.) Hedl.

1 record; on wood; 25 Dec. 2005 (OLS-L 287).

M. prasina Fr.

1 record; on wood; 15 Aug. 2005 (OLS-L 490), (TLC 038/1).

Mycoblastus fucatus (Stirt.) Zahlbr.

1 record; on the bark of plum tree; 10 June 2005 (OLS-L), (TLC 038/2).

Neofuscelia loxodes (Nyl.) Essl.

4 records; on roof tiles; 20 Aug. 2005 (OLS-L 387). P.

Parmelia saxatilis (L.) Ach.

2 records; on the bark of oak and poplar; 14 July 2005 (field record, not collected), P.

P. sulcata Taylor

21 records; on the bark of oak, apple tree, ash, maple, linden, alder, poplar, willow, cherry tree, on wood, 9 May 2005 (field record, not collected). Also recorded by Woźniak (1983).

Parmelina tiliacea (Hoffm.) Hale

15 records; on the bark of oak, apple tree, ash, linden, alder, poplar, 14 July 2005 (OLS-L 353). VU category, P. Also recorded by Woźniak (1983).

Pertusaria albescens (Huds.) M. Choisy \& Werner

3 records; on the bark of ash, maple and linden; 14 July 2005 (OLS-L 380). Also recorded by Woźniak (1983).

P. amara (Ach.) Nyl.

7 records; on the bark of ash, oak and linden; 14 July 2005 (field record, not collected). Also recorded by Woźniak (1983).

Phaeophyscia orbicularis (Neck.) Moberg

13 records; on the bark of elder, apple tree, ash, poplar, willow, on concrete; 25 Dec. 2005 (OLS-L 397). Also recorded by Woźniak (1983). 
Phlyctis argena (Ach.) Flot.

10 records; on the bark of oak, ash, maple, poplar and willow; 14 July 2005 (OLSL 337). Also recorded by Woźniak (1983).

Physcia adscendens (Fr.) H. Olivier

5 records; on the bark of oak, apple tree, ash and poplar; 14 July 2005 (OLS-L 338). Also recorded by Woźniak (1983).

Ph. caesia (Hoffm.) Fürnr.

4 records; on boulders and concrete; 14 July 2004 (OLS-L). Also recorded by Woźniak (1983).

Ph. dubia (Hoffm.) Lettau

4 records; on the bark of apple tree and ash, on metal; 20 Sept. 2005 (OLS-L 289).

Ph. stellaris (L.) Nyl.

4 records; on the bark of elder, apple tree and plum tree; 20 Sept. 2005 (OLS-L 302, 357).

Ph. tenella (Scop.) DC.

30 records; on the bark of elder, oak, apple tree, ash, horse-chestnut, maple, alder, rose, plum tree, poplar, willow, cherry tree, on wood and metal; 6 March 2005 (OLS-L 331).

Physconia enteroxantha (Nyl.) Poelt

10 records; on the bark of oak, apple tree, ash, poplar, willow, on wood; 14 July 2005 (OLS-L 367). Also recorded by Woźniak (1983).

Ph. grisea (Lam.) Poelt

5 records; on the bark of ash, poplar and willow; 14 July 2005 (OLS-L).

Ph. perisidiosa (Erichsen) Moberg

3 records; on the bark of elder, ash and poplar; 14 July 2005 (OLS-L 340). EN category.

Piccolia ochrophora (Nyl.) Hafellner

1 record; on the bark of willow; 10 Aug. 2005 (OLS-L 381). VU category.

Placynthiella icmalea (Ach.) Coppins \& P. James

2 records; on wood; 25 Dec. 2005 (OLS-L 285).

Pleurosticta acetabulum (Neck.) Elix \& Lumbsch

4 records; on the bark of oak and ash; 14 July (OLS-L 311). EN category, P. Also recorded by Woźniak (1983).

*Polysporina lapponica (Schaer.) Degel.

2 records; on thalli of Acarospora fuscata growing on roof tiles; 12 July 2005, det. D.

Kubiak (OLS-L 371, 372). NT category.

Porpidia soredizodes (Lamy ex Nyl.) J. R. Laudon

3 records; on roof tiles; 14 Sept. 2005 (OLS-L 417).

Protoparmelia hypotremella van Herk, Spier \& V. Wirth

1 record; on wood; 9 May 2005, rev. M. Kukwa (TLC 028/18) (OLS-L 306). 
Protoparmeliopsis muralis (Schreb.) M. Choisy

6 records; on cement-asbestos roofing material, wood, roof tiles and concrete; 14 July 2005 (field record, not collected).

Pseudevernia furfuracea (L.) Zopf

5 records; on the bark of oak and ash, on wood; 12 July 2005 (field record, not collected). P. Also recorded by Woźniak (1983).

Pycnora sorophora (Vain.) Hafellner

2 records; on wood; 20 May 2004 (OLS-L 341).

Ramalina farinacea (L.) Ach.

14 records; on the bark of oak, ash and linden; 20 Aug. 2005 (OLS-L 393). VU category, P. Also recorded by Woźniak (1983).

R. fastigiata (Pers.) Ach.

10 records; on the bark of oak, ash and linden; 20 Aug. 2005 (field record, not collected). EN category, $\mathrm{P}$.

R. fraxinea (L.) Ach.

8 records; on oak and the bark of ash; 20 Aug. 2005 (OLS-L 394). EN category, P. Also recorded by Woźniak (1983).

Rhizocarpon distinctum Th. Fr.

3 records; on roof tiles; 3 July 2006 (OLS-L 533).

Rinodina exigua (Ach.) Gray

1 record; on the bark of willow; 3 Aug. 2005 (OLS-L 299). VU category.

Scoliciosporum chlorococum (Graewe ex Stenh.) Vězda

11 records; on the bark of elder, oak, hazel, alder, plum tree, willow, cherry tree, on wood; 20 Sept. 2005 (OLS-L 301).

S. umbrinum (Ach.) Arnold

2 records; on roof tiles; 10 Aug. 2005 (OLS-L 513).

Strangospora pinicola (A. Massal.) Körb.

3 records; on wood; 20 Aug. 2005 (OLS-L). LC category.

Thelomma ocellatum (Körb.) Tibell

1 record; on wood; 6 June 2005 (OLS-L 390).

Trapeliopsis flexuosa (Fr.) Coppins \& P. James

1 record; on wood; 26 March 2005 (OLS-L 305).

T. granulosa (Hoffm.) Lumbsch

2 records; on wood; 20 Aug. 2004 (OLS-L 293).

T. pseudogranulosa Coppins \& P. James

1 record; on wood; 10 Aug. 2005 (OLS-L).

Verrucaria muralis Ach.

1 record; on concrete; 10 Aug. 2005 (OLS-L 384).

V. nigrescens Pers.

2 records; on concrete; 10 Aug. 2005 (OLS-L 383).

*Vouauxiella lichenicola (Lindsay) Petr. \& Syd.

1 record; on apothecia of Lecanora sp. [L. subfusca-group] growing on oak; 12 July 2005 (OLS-L). 
Xanthoria candelaria (L.) Th. Fr.

9 records; on the bark of oak, ash, horse-chestnut, maple, alder, willow, on metal; 20 Sept. 2005 (OLS-L 329). Also recorded by Woźniak (1983).

X. elegans (Link.) Th. Fr.

2 records; on concrete; 14 July 2005 (field record, not collected).

X. parietina (L.) Th. Fr.

12 records; on the bark of elder, apple tree, ash, maple, poplar, willow, on concrete and cement-asbestos roofing material; 25 Oct. 2005 (OLS-L 392). Also recorded by Woźniak (1983).

X. polycarpa (Hoffm.) Rieber

14 records; on the bark of elder, oak, apple tree, ash, rose, plum tree, poplar, cherry tree, willow, on metal; 20 Sept. 2005 (OLS-L 370). Also recorded by Woźniak (1983).

*Xanthoriicola physciae (Kalchbr.) D. Hawksw.

1 record; on apothecia of Xanthoria polycarpa growing on metal; 20 Sept. 2005 (OLS-L 370).

\section{ECOLOGICAL GROUPS}

It can be assumed that the analysed biota was made up in its entirety of synanthropic lichens (Fałtynowicz 1994; Olech 1998) occurring in anthropogenic habitats and on man-made substrates. According to Olech (1998), those lichens can be divided into three groups. The first group comprises macroautoapophytes (euapophytes) which are more likely to inhabit anthropogenic habitats than natural ecosystems. This group was represented, among others, by the following taxa: Amandinea punctata, Anaptychia ciliaris, Melanohalea exasperatula, Lecanora varia, Parmelina tiliacea, Phaeophyscia orbicularis, Physcia dubia, Ramalina fastigiata, $R$. fraxinea, Xanthoria parietina and $X$. polycarpa. In the investigated area, they were noted mostly on the bark of roadside trees or fruit trees. Most of them are coniophilous and nitrophilous lichens. They show a preference for habitats with ample sunlight and are resistant to draughts (Barkman 1958, Wirth 1995). The observed specimens had well-developed thalli and often produced numerous ascomata (e.g. Anaptychia ciliaris and the listed species of the genus Ramalina).

The second group of synanthropic lichens consists of mesoautoapophytes (hemiapophytes) which are equally often found in anthropogenic habitats and in natural ecosystems, among them Acarospora fuscata, Buellia griseovirens, Cladonia coniocraea, Evernia prunastri, Lecidella elaeochroma, Parmelia saxatilis, Pertusaria amara and Rhizocarpon distinctum.

The least populous group were the microautoapophytes which inhabit anthropogenic habitats only sporadically (Olech 1998). In the studied area, they were: Bacidina phacodes, Chaenotheca trichialis, Coenogonium pineti, Micarea misella and M. prasina. The first taxon grows on a varied range of substrates, but it is rarely noted outside of wooded areas (Cieśliński 2003, Fałtynowicz 2003). The remaining species are believed to be typical of forest habitats, and they are most often found in damp and shaded microniches (Cieśliński 2003, Czarnota 2007). In the investigated area, Chaenotheca trichialis, Micarea misella and M. prasina were noted on dead wood at 
the base of old fences or tree stumps surrounded by dense herbaceous vegetation. Coenogonium pineti was observed on tree bark, on lower parts of the trunk of Alnus glutinosa by the side of the river. This group of lichens is also inclusive of Anisomeridium polypori which was also found on the bark of ash, alder and willow trees. Until recently, this species was reported almost exclusively from forest communities in Poland (Fałtynowicz 2003), whereas other European sources (e.g. Earland-Benett 1994; Wirth 1997) claim that this species is able to colonize shaded microhabitats near human settlements.

\section{PROTECTED, THREATENED, RARE AND OTHERWISE INTERESTING SPECIES}

The area of the Nowica village is a habitat of many protected and threatened lichens. From among the 96 noted species, 14 are legally protected and 18 are threatened taxa in Poland (Cieśliński et al. 2006). The highest local frequency was observed in respect of: Parmelina tiliacea (VU, P), Ramalina farinacea (VU, P), R. fastigiata (EN, P) and $R$. fraxinea (EN, P).

The lichen biota of the Nowica region also features interesting species considered rare both in Poland and in Gdańsk Pomerania. The group of taxa with a few localities is inclusive of Bacidia adastra, Caloplaca obscurella, Chaenothecopsis savonica and Lecanora persimilis. The first one has been recently described (Sparrius and Aptroot 2003), and to date its only recorded localities in Poland are the city of Olsztyn (Kubiak and Sparrius 2004; Kubiak 2005), the Arboretum in Rogów (Kubiak and Szczepkowski 2006) and three sites in the region of Gdańsk Pomerania (Kukwa 2006). In the area of the Nowica village, Bacidia adastra was found on the bark of an old apple tree. The remaining species have very fine thalli that are difficult to spot during field observations which could explain the small number of localities recorded in Poland. Until recently, the most frequently observed species was Caloplaca obscurella (see Fałtynowicz 2003), found on the bark of a roadside willow. Chaenothecopsis savonica was noted only in the Puszcza Białowieska Forest (Sparrius 2003), in the Elblag High Plain adjacent to the Warmia Plain (Szymczyk 2007), as well as in the Puszcza Borecka Forest and in the Iława Lakeland (Zalewska - unpubl. materials). In the investigated area, the species was found on an old wooden fence. Lecanora persimilis has been recorded in Poland at three older localities (Fałtynowicz 2003) and at several subsequent localities (Jando and Kukwa 2002; Czyżewska 2003a; Łubek and Cieśliński 2004; Kubiak 2005; Kukwa 2006). In the studied area, it was observed on the exposed wood of an old roadside ash tree.

Species which are rarely found on the regional scale are: Anaptychia ciliaris, Bacidina phacodes, Parmelina tiliacea, Piccolia ochrophora, Polysporina lapponica, Protoparmelia hypotremella, Pycnora sorophora, Thelomma ocellatum and Xanthoria elegans (Fałtynowicz and Kukwa 2003, 2006). The most intriguing discovery was that of Lecidella scabra, a montane epilithic lichen found on old roof tiles in Nowica. This lichen was believed to be extinct in Gdańsk Pomerania (Fałtynowicz and Kukwa 2003), but it was recently discovered at several localities on the stone walls of historical buildings (Fałtynowicz and Kukwa 2006; M. Kukwa, pers. comm.). In Europe, this species was also noted on similar, anthropogenic substrates (Brightman and Seaward 1977; Gilbert 1990). 
Lichens growing on corroded metal were another interesting group of species. The study revealed 7 taxa that sometimes occur on this type of substrate (Brightman and Seaward 1977; Gilbert 1990): Caloplaca holocarpa, Candelariella aurella, C. vitellina, Lecanora conizaeoides, Physcia dubia, Ph. tenella, Xanthoria candelaria and $X$. polycarpa. Those lichens were observed on the metal parts of old farm machines, such as the plough and the trailer.

\section{DISCUSSION}

Although the village of Nowica covers a small area, the presented lichen species could be a model example of lichen biota in rural areas with traditional, low-intensity farming systems. There are no large animal farms in the village, its immediate vicinity and surroundings, which could drastically raise the local levels of ammonia and other nitrogen compounds that contribute to the expansion of nitrophilous lichens and to the massive elimination of acidophilic species (see Benfield 1994; van Herk 1999; 2002; Wolseley et al. 2006a). In the majority of farms the stocking density is low or moderate (up to 20 animals), grasslands occupy large areas and arable land is not sprayed with slurry. Similarly to other areas of this type, the eutrophication of tree bark, wooden fences and other substrates leads to the emission of ammonia from decomposing manure stored by farm buildings or used as fertilizer. Outside the reach of ammonia gas (up to $300 \mathrm{~m}$ from the source of emission, see the works of M. A. Sutton et al., as cited by Wolseley et al. 2006a), chemical changes in the surface of the substrate are caused by the sedimentation of dust containing ammonia derivatives (e.g. ammonium sulfate or nitrate) precipitated in the form of dry or wet deposition as well as chemical fertilizers as nitrates and phosphates.

It should also be noted that industrial, municipal and traffic-related air pollution, which has an opposing effect on the substrate and directly eliminates sensitive species of fruticose and foliose lichens (Hawksworth and Rose 1970; Gries 1996), does not have a significant effect on the investigated lichen biota. Vehicle traffic on roads intersecting Nowica is not very intense, and the main sources of sulfur dioxide and nitrogen oxide emissions from the combustion process could be the Elblag Combined Heat and Power Plant and the city of Elblag situated $25 \mathrm{~km}$ to the west. Yet owing to the distance and the low level of pollution (advanced filtering system, biogas combustion), the plant and the city of Elblag have a small environmental impact. Direct measurements have not been performed in Nowica, but in view of the available data, the mean annual concentration of $\mathrm{SO}_{2}$ and $\mathrm{NO}_{2}$ in ambient air in the county of Braniewo is among the lowest in the Province of Warmia and Mazury (mean annual maxima: $\mathrm{SO}_{2}-6.7 \mu \mathrm{g} / \mathrm{m}^{3}, \mathrm{NO}_{2}-5.1 \mu \mathrm{g} / \mathrm{m}^{3}$, acc. to Jamiołkowski 2002). In 2003-2005, mean annual $\mathrm{SO}_{2}$ concentrations in Elbląg reached $2 \mu \mathrm{g} / \mathrm{m}^{3}$ (the allowable level in 2005 was $20 \mu \mathrm{g} / \mathrm{m}^{3}$ ), while mean annual $\mathrm{NO}_{2}$ concentrations were in the range of $20-26 \mu \mathrm{g} / \mathrm{m}^{3}$ (the allowable level in 2005 was $50 \mu \mathrm{g} / \mathrm{m}^{3}$ ) (KacprzykChynczewska 2006).

Available data suggest that the investigated area is characterized by an average level of substratum eutrophication and a low level of gaseous pollution. Under such conditions, repeatable distribution patterns of epiphytic species were observed on free-standing and roadside trees. The predominant species occurring on the bark of deciduous trees were fruticose lichens, mainly Evernia prunastri and Ramalina 
farinacea. The following species were less abundant: Ramalina fraxinea, $R$. fastigiata, the foliose Physconia enteroxantha, Physcia tenella, Phaeophyscia orbicularis, Parmelia sulcata, Melanohalea exasperatula, as well as species with crustose thalli, mostly Pertusaria albescens, P. amara, Phlyctis argena and small specimens of Lecanora carpinea, L. chlarotera and L. argentata. In addition to Ramalina spp. and Physcia s.l., the group of nitrophilous lichens was also inclusive of Xanthoria parietuna, X. polycarpa, Amandinea punctata, Candelariella reflexa and C. xanthostigma. Other species, e.g. Anaptychia ciliaris, Pleurosticta acetabulum and smaller specimens of Melanelixia subargentifera, Physcia stellaris and Physconia perisidiosa occurred less frequently, but in the form of large thalli. Interesting, relatively unexplored members of those lichen communities were Caloplaca obscurella, L. flavosorediata, Piccolia ochrophora and Rinodina exigua which are found in other areas of northern Poland. In future studies, attention should be also paid to Protoparmelia hypotremella and Strangospora pinicola, often found on roadside trees (Zalewska - unpublished materials), which were observed on wood in the investigated area. The study area is distinguished by relatively frequent and abundant populations of Parmelina tiliacea. According to Cieśliński (2003), this epiphyte is still widespread in the Old Prussian Lowland adjacent to the Warmia Plain, but it has a decreasing share of the mesoregions situated further to the east. The high frequency of Candelariella reflexa is another specific feature of the investigated lichen biota. This taxon is less commonly identified and generally believed to be less widespread than the similar C. xanthostigma (Fałtynowicz 1992; Cieśliński 2003).

Epiphytes growing on roadside and free-standing trees are one of the most endangered ecological lichen groups in Poland (Czyżewska 2003b). Their populations have been most drastically reduced in industrialized areas with the greatest air pollution, in particular in the lowland areas of Upper Silesia and Opole Silesia. Communities which are most typically developed and least threatened by toxic compounds are still found in north-eastern Poland (Czyżewska 2003b; Cieśliński 2003). The felling of roadside trees during road construction poses one of the fastest growing threats for this ecological group, even in the above area. Such projects are initiated "to improve the safety" of roads which are not regularly upgraded. Despite frequent protests of ecologists, this argument is frequently abused by the authorities.

\section{FINAL REMARKS}

In view of growing pressure, research studies are needed to investigate the condition of and changes in epiphytic communities in rural areas. Observations of lichens growing on other anthropogenic substrates will provide complementary information on the hemerophily of many species and will validate data relating to lichens that, until now, have been associated primarily with forest communities, as discussed in this study. Such studies should cover the broadest possible spectrum of substrates and rarely investigated wet and shaded microhabitats. The conducted study has also shown that open areas can be a habitat of rare species whose distribution in Poland remains relatively unknown.

To conclude, rural areas which are characterized by a low level of substrate eutrophication and which are not affected by air pollution provide habitat for potentially valuable and interesting lichen biota. The structure of the lichen biota of the 
village of Nowica can be used as a contemporary model and a reference point for other studies of this type. In the future, the collection of larger quantities of data will support more advanced analyses similar to the research of ruderal vascular flora (see Wołkowycki 2000).

Acknowledgements. The authors would like to thank Martin Kukwa, Ph.D., for verifying the determinations and for his critical evaluation of this paper. We would also like to thank two anonymous reviewers for their comments and improvements to the draft manuscript.

In the course of this study, the first author received a grant from the European Social Fund and the central budget as part of the Integrated Regional Development Operational Program 2006-2007.

\section{REFERENCES}

Barkman J. J. 1958. Phytosociology and ecology of cryptogamic epiphytes. Van Gorcum \& Comp., Assen. [Reissued 1969], 628 pp.

Benfield B. 1994. Impact of agriculture on epiphytic lichens at Plymtree, East Devon. Lichenologist 26(1): 91-96.

Brightman F. H., Seaward M. R. D. 1977. Lichens of man-made substrates. (In:) M. R. D. Seaward (ed.), Lichen ecology. Academic Press, London, San Francisco, p. 253-289.

Bystrek J., Kolanko K. 2000. Porosty (Lichenes) Puszczy Knyszyńskiej. Wyd. Inst. Biologii Uniwersytetu w Białymstoku, Białystok, 98 pp.

Cieśliński S. 2003. Atlas rozmieszczenia porostów (Lichenes) w Polsce Północno-Wschodniej. Phytocoenosis 15 (N.S.), Suppl. Cartogr. Geobot. 15: 1-426.

Cieśliński S., Czyżewska K. 1998. Lichens as indicators of the synanthropization of plant cover and the environment. (In:) J. B. Faliński, W. Adamowski \& B. Jackowiak (eds), Synanthropization of plant cover in new Polish research. Phytocoenosis 10 (N.S.), Suppl. Cartogr. Geobot. 9: 257-267.

Cieśliński S., Czyżewska K., Fabiszewski J. 2006. Red list of the lichens in Poland. In: Z. Mirek, K. Zarzycki, W. Wojewoda, Z. Szeląg (eds), Red list of plants and fungi in Poland. W. Szafer Institute of Botany, Polish Academy of Sciences, Kraków, p. 72-89.

Cieśliński S., Fałtynowicz W. 1993. Note from editors. (In:) S. Cieśliński, W. Fałtynowicz (eds.), Atlas of the geographical distribution of lichens in Poland. Part I. W. Szafer Institute of Botany, Polish Academy of Sciences, Kraków, p. 7-9.

Czarnota P. 2007. The lichen genus Micarea (Lecanorales, Ascomycota) in Poland. Polish Bot. Stud. 23: 1-199.

Czyżewska K. 2003a Lichens and lichenicolous fungi in the Bolimów Landscape Park. Monogr. Bot. 92: 234-277.

Czyżewska K. 2003b. Ocena zagrożenia bioty porostów Polski. Monogr. Bot. 91: 241-249.

Earland-Benett P. M. 1994. A note on Anisomeridium nyssaegenum in East Anglia. Britsh Lich. Soc. Bull. 74: $28-29$.

Fałtynowicz W. 1992. The lichens of Western Pomerania. An ecogeographical study. Polish Bot. Stud. 4: $1-183$.

Fałtynowicz W. 1994. Propozycja klasyfikacji porostów synantropijnych. Wprowadzenie do dyskusji. (In:) J. Kiszka, J. Piórecki, (eds), Porosty apofityczne jako wynik antropopresji. Materiały z Sympozjum, Bolestraszyce, 4-9 wrzesień 1993. Arboretum Bolestraszyce 2: 21-30.

Fałtynowicz W. 2003. The lichens, lichenicolous and allied fungi of Poland. An annotated checklist. (In:) Z. Mirek (ed.), Biodiversity of Poland 6. W. Szafer Institute of Botany, Polish Academy of Sciences, Kraków, 435 pp.

Fałtynowicz W., Kukwa M. 2003. Red list of threatened lichens in Gdańsk Pomerania. Monogr. Bot. 91: 64-77.

Fałtynowicz W., Kukwa M. 2006. List of lichens and lichenicolous fungi of Gdańskie Pomerania. Acta Botanica Cassubica, Monogr. 2: 1-106.

Fałtynowicz W., Sulma T. 1994. Distributional data to epiphytic taxa of the Pertusariaceae (lichenized Ascomycotina) in Poland. Fragm. Florist. Geobot. Polonica 39(1): 291-296.

Fałtynowicz W., Tobolewski Z. 1989. The lichenized Ascomycotina of Kaszuby Lake District, Northern Poland. Fragm. Florist. Geobot. 34(3-4): 445-521. 
Gilbert O. L. 1990. The lichen flora of urban wasteland. Lichenologist 22 (1): 87-101.

Gries C. 1996. Lichens as indicators of air pollution. In: T. H. Nash III (ed.), Lichen biology. University Press, Cambridge, p. 240-254.

Groner U. 2006. The genus Chaenothecopsis (Mycocaliciaceae) in Switzerland, and a key to the European species. Lichenologist 38(5): 395-406.

Hawksworth D.L., Rose F. 1970. Qualitative scale for estimating sulphur dioxide air pollution in England and Wales using epiphytic lichens. Nature 227: 145-148.

Hawksworth D. L. Blanco O., Divakar P. K., Ahti T., Crespo A. 2008. A first checklist of parmelioid and similar lichens in Europe and some adjacent territories, adopting revised generic circumscriptions and with indications of species distributions. Lichenologist 40(1): 1-21.

Hafellner J. 2004. A revision of Maronella laricina and Piccolia ochrophora. Symb. Bot. Ups. 34 (1): 8796.

Herk van C. M. 1999. Mapping of ammonia pollution in the Netherlands. Lichenologist 31(1): 9-20.

Herk van C. M. 2002. Epiphytes of roadside trees as an indicator of eutrophication in the Netherlands. (In:) P. L. Nimis., C. Scheidegger \& P. A. Wolseley (eds), Monitoring with lichens - monitoring lichens. Kluwer, Dodrecht, p. 285-289.

Jando K., Kukwa M. 2002. Porosty, grzyby naporostowe i nażywiczne rezerwatu "Wiszące torfowisko nad jeziorem Jaczno" oraz terenów przyległych w Suwalskim Parku Krajobrazowym (NE Polska). Parki Nar. Rez. Przyr. 22(3): 3-17.

Jamiołkowski A. 2002. Wstępna ocena jakości powietrza w województwie warmińsko-mazurskim. (In:) M. Planter \& S. Różański (eds), Raport o stanie środowiska województwa warmińsko-mazurskiego w 2001 rok. Biblioteka Monitoringu Środowiska, Wojewódzki Inspektorat Ochrony Środowiska, Olsztyn. p. 178-186.

Kacprzyk-Chynczewska M. 2006. Ocena stanu zanieczyszczenia powietrza atmosferycznego na terenie województwa warmińsko-mazurskiego w roku 2005. (In:) Z. W. Krajewski (ed.), Raport o stanie środowiska województwa warmińsko-mazurskiego w 2005 rok, Biblioteka Monitoringu Środowiska, Wojewódzki Inspektorat Ochrony Środowiska, Olsztyn. p. 81-91

Kauff F., Büdel B. 2005. Ascoma ontogeny and apothecial anatomy in the Gyalectaceae (Ostropales, Ascomycota) support the re-establishment of the Coenogoniaceae. Bryologist 108 (2): 272-281.

Kiszka J. 1994. The apophytic lichens as a result of the anthropopression within the natural environment of the Carpathian Mts. (In:) J. Kiszka, J. Piórecki, (eds.), Porosty apofityczne jako wynik antropopresji. Materiały z Sympozjum, Bolestraszyce, 4-9 wrzesień 1993. Arboretum Bolestraszyce 2: 5-20.

Kondracki J. 2001. Geografia regionalna Polski. Ed. 2. Wyd. Naukowe PWN, Warszawa, 441 pp.

Kubiak D. 2005. Lichens and lichenicolous fungi of Olsztyn town (NE Poland). Acta Mycol. 40 (2): 125174.

Kubiak D., Sparrius L. B. 2004. Bacidia adastra, B. brandii and B. neosquamulosa found in North-Eastern Poland. Graphis Scripta 16 (2): 61-64.

Kubiak D., Szczepkowski A. 2006. Lichens of the Rogów Forest of Warsaw Agricultural University (1): Arboretum, Popień and Zimna Woda reserves. Ann. Warsaw Agricult. Univ. SGGW, For. and Wood Technl. 60: 51-63.

Kukwa M. 2006 (2007). Nowe stanowiska rzadkich i interesujących porostów na Pomorzu Gdańskim. Cześć III. (In:) T. S. Olszewski, R. Afranowicz, K. Bociąg. (eds), Współczesne kierunki badań botanicznych - w 80. rocznice urodzin Pani Profesor Hanny Piotrowskiej. Acta Botanica Cassubica 6: 141-152.

Kuziel S. 1964. Porosty epifityczne drzew owocowych w kotlinie Łącka i okolic. Łódzkie Tow. Nauk., Prace Wydz. III Nauk Mat.-Przyr. 98: 1-42.

Łubek A., Cieśliński S. 2004. Distribution of lichens and lichenicolous fungi in the Świętokrzyski National Park. Acta Mycol. 39(2): 173-252.

Olech M. 1998. Apophytes in the lichen flora of Poland. (In:) J. B. Faliński, W. Adamowski, B. Jackowiak (eds.), Synanthropization of plant cover in new Polish research. Phytocoenosis 10 (N.S.), Suppl. Cartogr. Geobot. 9: 251-255.

Orange A., James P. W., White F. J. 2001. Microchemical methods of the identification of lichens. British Lichen Society London, $101 \mathrm{pp}$.

Regulation of the Ministry of the Environment. 2004. Rozporządzenie Ministra Środowiska z dnia 9 lipca 2004 r. w sprawie gatunków dziko występujących grzybów objętych ochroną. Dziennik Ustaw 04.168.1765 z dnia 28 lipca 2004 r. 
Sparrius L. 2003. Contribution to the lichen flora of the Białowieża Forest and the Biebrza valley (Eastern Poland). Herzogia 15: 155-160.

Sparrius L. B., Aptroot A. 2003. Bacidia adastra, a new sorediate lichen species from Western Europe. Lichenologist 35(4): 275-278.

Sulma T., Fałtynowicz W. 1988. Materiały do rozmieszczenia porostów z rodziny Parmeliaceae w Polsce. Acta Mycol. 23(1): 107-123.

Szymczyk R. 2007. Rzadkie i interesujące gatunki porostów i grzybów naporostowych na Wysoczyźnie Elbląskiej (północna Polska). Fragm. Florist. Geobot. Polonica 14(1): 167-173.

Tobolewski Z. 1983. Porosty (Lichenes). (In:) J. Szweykowski, T. Wojterski (eds), Atlas of geographical distribution of spore-plants in Poland. VIII. PWN, Warszawa-Poznań,

Tobolewski Z. 1988. Porosty (Lichenes). (In:) J. Szweykowski, T. Wojterski (eds), Atlas of geographical distribution of spore-plants in Poland. IX. PWN, Warszawa-Poznań,

Wirth V. 1995. Die Flechten Baden-Württembergs. Ulmer, Stuttgart, 1006 pp.

Wirth V. 1997. Einheimisch oder eingewandert? Über die Einschätzung von Neufunden von Flechten. In: L. Kappen (ed.), New species and novel aspects in lichenology and physiology of lichens. In honour of O. L. Lange. Bibl. Lichenol. 67: 277-289.

Wolseley P. A., James P. W., Theobald M. R., Sutton M. A. 2006. [Wolseley et al. 2006a]. Detecting changes in epiphytic lichen communities at sites affected by atmospheric ammonia from agricultural sources. Lichenologist 38(2): 161-176.

Wolseley P. A., Stofer S., Mitchell R., Truscott A.-M., Vanbergen A., Chimonides J. Scheidegger C. 2006. [Wolseley et al. 2006b]. Variation of lichen communities with landuse in Aberdeenshire, UK. Lichenologist 38(4): 307-322.

Wołkowycki D. 2000. Różnicowanie i ujednolicanie się flor ruderalnych w warunkach izolacji środowiskowej. Monogr. Bot. 87: 1-163.

Woźniak I. 1983. Porosty Niziny Warmińskiej. Master thesis. Zakład Taksonomii Roślin Uniwersytetu im. Adama Mickiewicza w Poznaniu (Department of Plant Taxonomy, Adam Mickiewicz University in Poznań), Poznań, 83 pp.

\section{Porosty w krajobrazie rolniczym na Równinie Warmińskiej}

\section{Streszczenie}

Praca prezentuje wyniki badań lichenologicznych, których celem było zarejestrowanie gatunków porostów w krajobrazie rolniczym wsi Nowica na Równinie Warmińskiej (Fig. 1). Plechy porostów zbierano ze wszystkich substratów antropogenicznych. Przedstawiono 104 taksony, w tym 96 gatunków porostów i 8 gatunków grzybów niezlichenizowanych. Spośród odnotowanych grzybów zlichenizowanych - 14 to gatunki prawnie chronione, a 18 znajduje się na Czerwonej liście porostów zagrożonych. Biota analizowanego terenu zawiera gatunki rzadkie w Polsce, notowane na pojedynczych lub nielicznych stanowiskach, np. Bacidia adastra, Caloplaca obscurella, Chaenothecopsis savonica i Lecanora persimilis. Zarejestrowano także stanowisko Lecidella scabra, do niedawna uważanego za wymarły na Pomorzu Gdańskim. Listę gatunków w całości stanowią porosty hemerofilne, zasiedlające siedliska i substraty wytworzone przez człowieka. Analizowana biota może stanowić model składu gatunkowego porostów na terenach rolniczych o niewielkim poziomie eutrofizacji podłoży, położonego poza zasięgiem oddziaływania zanieczyszczeń powietrza. 